\title{
Unique and Stable Water-Fuel Emulsions
}

\author{
Yu.V. Vorobyov ${ }^{1}$, G.S. Baronin ${ }^{1}$, A.V. Dunaev², D. Stavrev ${ }^{3}$, D. Dimitrov ${ }^{3}$, \\ R. Dimitrov ${ }^{3}$, N.V. Voronin ${ }^{1}$, Yu.Yu. Vorobyov ${ }^{4}$, G.P. Kuznetsov ${ }^{5}$, I.G. Assovskiy ${ }^{5}$ \\ ${ }^{1}$ Tambov State Technical University, 106, Sovetskaya st., Tambov, 392000, Russia, \\ ${ }^{2}$ Federal Scientific Agricultural Engineering Center VIM, 5, 1st Institutsky proezd, Moscow, 109428, Russia; \\ ${ }_{3}$ Technical University of Varna, 1, Studentska St., Varna, 19010, Bulgaria; \\ ${ }^{4}$ St. Petersburg State University, 7/9, Universitetskaya naberezhnaya, St. Petersburg, 199034, Russia \\ ${ }^{5}$ Institute of Chemical Physics named after N. N. Semenov, Russian Academy of Sciences, 4, Kosygina st., Moscow, 4119991, Russia; \\ * Corresponding author. Tel.: +7 49593972 67. E-mail: assov@chph.ras.ru
}

\begin{abstract}
The paper deals with the issues of increasing the efficiency of heat engines using the example of reciprocating internal combustion engines. The prospects for the application of aqueous diesel fuel compositions are shown, the advantages and disadvantages of the existing methods for producing such compositions are discussed. Particular attention is paid to the application of the intensive mechanical activation method to obtain stable aqueous diesel fuel emulsions. The results of comparative tests of such water-fuel emulsions are presented. The results of an experimental study of the structure and temperature modes for various diesel fuel and water-fuel emulsion (33\% water) single droplets when they ignite in the air at the atmospheric pressure are also presented.
\end{abstract}

\section{Keywords}

Heat engines, internal combustion engines, diesel fuel, water-fuel emulsions, fuel mechanical activation.

(C) Yu.V. Vorobyov, G.S. Baronin, A.V. Dunaev, D. Stavrev, D. Dimitrov, R. Dimitrov, N.V. Voronin, Yu.Yu. Vorobyov, G.P. Kuznetsov, I.G. Assovskiy, 2019

\section{Introduction}

A variety of heat engines are widely used in many sectors of the economy. Therefore, the issues of improving the efficiency of heat engines are relevant to the economies of the developed countries and therefore are actively explored by their research centers. Reciprocating internal combustion engines (ICE) are the most common examples of heat engines, in which motor fuel is not only a source of heat energy, but also the working fluid necessary to convert heat to the kinetic energy of a vehicle. Therefore, the energy efficiency of the internal combustion engine depends on the characteristics of ignition and combustion of the fuel [1], as well as on the thermodynamic characteristics of its combustion products (engine working fluid).

The laws of thermodynamics show that in order to increase the energy efficiency of a heat engine, it is necessary to increase the maximum temperatures and pressures of the working fluid, as well as to reduce its average molecular weight [2]. Hence the main contradiction between the thermodynamic efficiency and the environmental safety of the internal combustion engine arises, since complete combustion of the fuel in the engine leads to the increase in the average molecular weight (mainly due to the oxidation of $\mathrm{CO}$ to $\mathrm{CO}_{2}$ ), the growth in the maximum temperature of the combustion products increases the content of nitrogen oxides in the products [3], and the growth in the maximum pressure stimulates soot formation (see, for example, [4]). To eliminate the environmental damage from the abovementioned components of the exhaust gases of the internal combustion engine, it is necessary to use selective catalytic burners (for $\mathrm{CO}$ and soot) and more complex converters for nitrogen oxides. Therefore, the solution to the problem of increasing the efficiency of the internal combustion engine comes down to the search for a reasonable compromise between the requirements of thermodynamics and ecology. As such a compromise we propose to use stabilized mechanoactivated water-fuel emulsions. 
Water vapor has long been used as a working fluid in various heat engines of external combustion (steam engines, steam turbines, etc.), as well as in the working fluid in internal combustion engines, in power plants, for example, using water-coal suspensions or water-fuel oil emulsions as fuel. The advantages and disadvantages of using water vapor are well known. The advantages of including water in the composition of a composite motor fuel (for example, in the form of water-fuel emulsions) include, first of all, saving of hydrocarbon fuel, reducing both the fire hazard of the fuel used and the emission of the harmful components of exhaust gases into the atmosphere [5 - 10], as well as the additional possibility to purposefully influence the thermodynamic characteristics of combustion products [2]).

The main disadvantage of water-fuel emulsions is their gradual separation during storage, which leads to the loss of their competitive advantages. For this reason, from time to time, efforts are being made to create systems for the rapid preparation of emulsions immediately before injection into the engine combustion chamber (see, for example, [5]). This approach requires changes in the engine design and the corresponding additional costs. Therefore, another urgent solution to the problem is to find ways to improve the technology for preparing water-fuel emulsions (WFE), which retain their structure and properties for a sufficiently long period of storage time.

\section{The impact of WFE on the ICE work. Research overview}

Based on the experience gained in the use of water compositions of hydrocarbon fuels [6 - 18] in the ICE, it can be concluded that burning of water-fuel composition instead of pure fuel in the ICE has the following positive effects on the engine operation:

- reducing the temperature and preventing explosive or detonation combustion of the fuel;

- smoothing the dynamics of pressure rise in the cylinders;

- increasing the average pressure in the cylinders;

- increasing the completeness of the fuel combustion;

- increasing the efficiency of the ICE;

- reducing the content of harmful substances in exhaust gases (EG) (2-3 times of soot, $\mathrm{NO}_{x}, \mathrm{SO}_{x}$; significantly - of carcinogenic benzopyrene $\mathrm{C}_{20} \mathrm{H}_{12}$, (Fig. 1);

- cleaning the combustion chamber from carbon;

- ensuring the operation of the ICE in a sparing mode: wear, vibration and engine noise reduction.

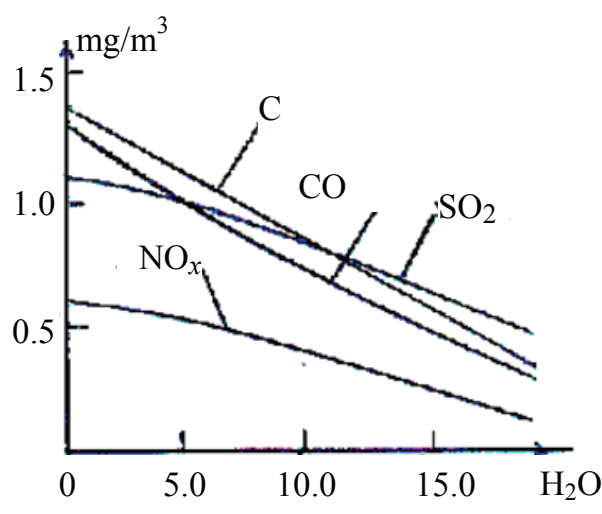

Fig. 1. Concentration of harmful substances in combustion products depending on the moisture content in WFE [8]

Using WFE without changing the fuel supply system in the ICE or boilers provides the following advantages:

- significant savings in the hydrocarbon component of the fuel due to the increase in the volume occupied by the fuel by $15-50 \%$;

- reduction of fuel viscosity (lower than the initial fuel viscosity);

- preservation of the fuel atomization quality in all ICE operation modes;

- improvement of diesel engines and boilers;

- modern preparation of WFE creates high quality fuel even in the presence of "water lenses" in the storage tanks.

Usually, WFE after storage is less effective than that prepared just before burning, which does not contain emulsifiers and stabilizers giving carbon deposits. However, ensuring long-term stability of WFE is possible only with its careful, time-consuming preparation.

The pioneer of the WFE introduction for diesel engines is the navy. For this purpose, the USSR leading research institutes conducted intensive studies, the results of which were applied in the mid-80s. So, from 1985 to 1989 , the UKDG-85, UKDG-89 units were developed for the WFE preparation for main marine diesel engines with a capacity of up to $10,600 \mathrm{bhp}$. At the same time, WFE provided the reduction in fuel consumption by $12 \%$, the decrease in exhaust gas temperature by $8-10{ }^{\circ} \mathrm{C}$, the significant reduction in the content of harmful components in exhaust gases and heat density in the cylinder-piston group (CPG). In the UKDG units, a set of devices performs multistage dispersion of the mixture, homogenizing the mixture by intense cavitation effects from highfrequency ultrasound. 
The dependence of the WFE efficiency for diesel engines and boilers on the dispersion and water content, the degree of modification of fuels, and the method of WFE application was established [8 - 10]. Therefore, the UKDG Odessa "CET Hydrofuel" units ensured the effective operation of diesel engines and boiler units on WFE with a water content of $5-30 \%$. The dispersion of $98 \%$ water droplets is $1-5$ microns, their maximum is 20 microns, while the dispersion of fuel droplets is $3-5$ microns. In this case, the fuel equipment in all modes works without failures.

It was found that WFE with $15-20 \%$ water gives the greatest environmental effect, WFE with $30 \%$ water content gives the greatest effect on the disposal of pollution, the greatest reduction in specific fuel consumption $(\mathrm{g} / \mathrm{kWh})$ is achieved with $17-25 \%$ water content. When watering WFE over $20 \%$, the combustion efficiency is reduced, but while ensuring the stability of combustion, it is possible to utilize any waste [9].

By 1990, UKDG units were commissioned on 50 ships of the USSR Navy, 9 of them - on ships of the Black Sea Shipping Company. Abroad, the introduction of WFE was conducted by the leading diesel engine building companies in connection with the International Agreement "IMO" on the restriction of harmful substances in exhaust gases of ship propulsion systems. Thus, the Finnish company "Vyartsilya", after lengthy tests, refused to inject water into the cylinders and uses WFE with $30 \%$ water and $0.5 \%$ combustion stabilizing additive. MAN B\&W corporation in medium speed 48/60IS and 58/60IS diesel engines on cruise ships uses WFE, obtained by hydrodynamic and

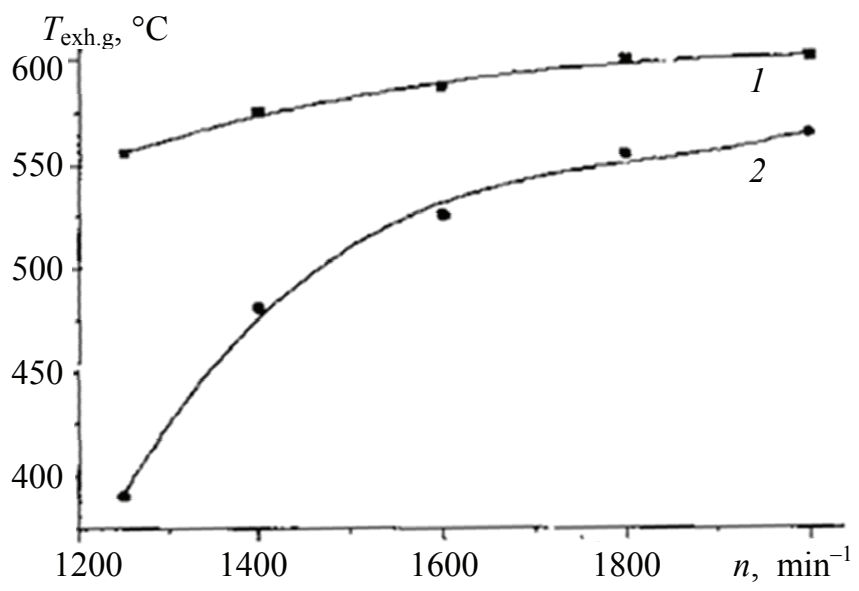

Fig. 2. Correlation between exhaust gas temperature and diesel engine speed [16]:

1 - diesel fuel; 2 - WFE ultrasonic methods for fuel oil with $15 \%$ water. Here, the content of $\mathrm{NO}_{x}$ in the exhaust gases of diesel engines is reduced to $6.7 \mathrm{~g} / \mathrm{kWh}$, which is two times less than the IMO standards. The use of WFE on passenger ships indicates a high reliability of the ICE operation on WFE.

The wear control of the cylinder-piston group (CPG) when working with WFE was first carried out in [9] on a marine diesel engine 6DKRN 74/160-3. It was found that the wear rates of CPG components when using WFE do not exceed the wear rates when operating on dehydrated fuel oil [9].

Experimental and theoretical studies of the waterfuel mixtures combustion are actively conducted in many countries, which affected the understanding of the complexity of the physicochemical processes accompanying the WFE combustion. Thus, the authors $[16,15]$ believe that the activation of a mixture of water and hydrocarbons creates new phases of substances stabilized by electrostatic forces from induced charges. Due to them, free radicals arise in mixtures, which allows for low-temperature combustion, more complete fuel combustion, the sharp decrease in the content of incomplete combustion products in the exhaust gas, the increase in the engine service life and efficiency.

Figures 2 and 3 demonstrate the results of testing the YMZ-2E8L engine using the composition of diesel fuel with $20 \%$ water obtained in St.-Petersburg Technological Institute [16]. It is seen that the use of WFE can significantly reduce the temperature of the exhaust gases and the $\mathrm{CO}$ content in them in a wide range of changes in the frequency of the diesel engine rotation.

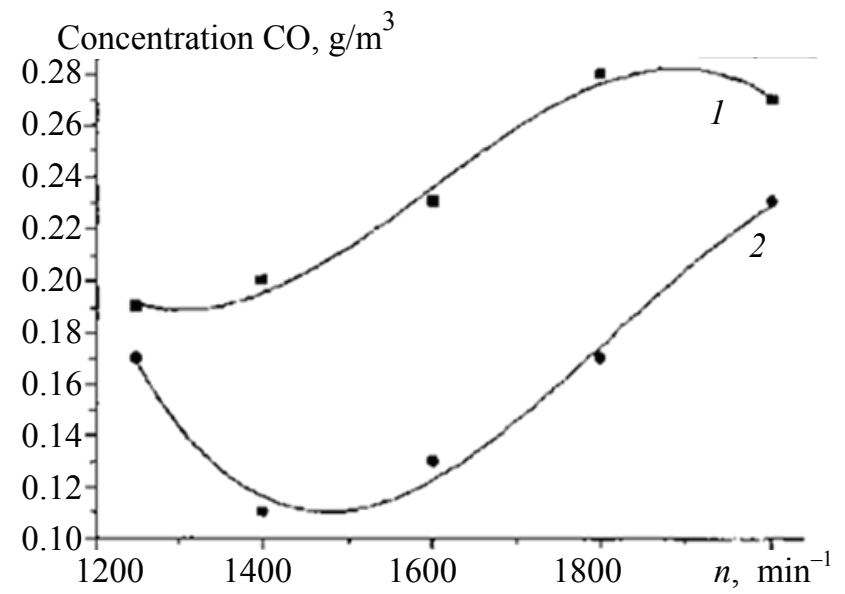

Fig. 3. Correlation between $\mathrm{CO}$ concentration in exhaust gas and diesel engine speed [16]: 1 - diesel fuel; 2 - WFE 


\section{Experimental study of the characteristics of WFE droplets ignition and combustion}

\section{Preparation of water-fuel compositions and activated diesel fuel}

We used highly stable WFE obtained in Tambov State Technical University. The initial fuel composition: $65 \%$ diesel fuel, $33 \%$ distilled water, $2 \%$ emulsifiers according to patent No. 2365618. The following compositions were taken:

- component 1 - anionic surfactants (alkyl sulfates of the general formula), $0.48 \%$; nonionic surfactants (sorbitanoleate), $0.15 \%$; $0.64 \%$;

- component 2 - polyolefins (poly-alpha-olefins),

- component 3 - betaine, $0.22 \%$;

- component 4 - nitrated oil, $0.44 \%$;

- engine oils or their promoters, $0.072 \%$.

Component 1 was injected and mixed in 3.3 liters of water, and the rest was injected and mixed in 7.5 liters of diesel fuel. The resulting compositions of water and fuel were poured into a common container, from which the mixture was pumped through an activator according to patent No. 2550203 (Fig. 4) for $3 \mathrm{~min} \mathrm{[18].} \mathrm{Chemotological} \mathrm{and} \mathrm{chromatographic}$ analyzes of the obtained WFE showed the following parameters:

- composition: water - $33 \%$, L-0.2 diesel fuel according to GOST $305-65 \%$, emulsifiers and stabilizers $-2 \%$;

- properties: density is $897 \mathrm{~kg} / \mathrm{m}^{3}$, flash point is not lower than $67^{\circ} \mathrm{C}$, limit temperature of filterability in accordance with GOST 305 is not higher than $-5^{\circ} \mathrm{C}$, corrosion on a copper plate according to class I does not show, sulfur content determined by the method GOST 32511-2013 corresponds to the norm.

Comparison of the of WFE and diesel fuel compositions, determined on the chromatograph "Crystallux 4000" in a certified Tambov forensic laboratory, showed the following:

1. The share of light hydrocarbons in WFE (without taking them into account in the complex of activated Euro diesel fuel and VNIITiN diesel fuel) is up to $\mathrm{C}_{15} \mathrm{H}_{32}$ greater than in activated Euro diesel fuel and significantly higher than in non-activated diesel fuel.

2. The share of heavy hydrocarbons in WFE since $\mathrm{C}_{16} \mathrm{H}_{34}$ is noticeably less than in non-activated and activated Euro diesel fuel.

The prevalence of light components and lower content of heavy components in WFE in the diesel fuel activated in TSTU and aged for 57 days is extraordinary and causes a significant (by $20-27 \%$ ) reduction in the fuel consumption, testifies to the high quality of WFE from TSTU, which is confirmed by bench tests in KamAZ-740, YaMZ-236 and ZMZ-406 engines in VUNC VVA VVC MO (Voronezh).

The WFE obtained on 17.12.2017 was sustained until April 2018 and again subjected to chemical immunological and chromatographic control, which, like the activated diesel fuel, showed invariance of the WFE properties. The comparison of the diesel fuel and WFE spectrograms shows the superiority of WFE to diesel fuel in a variety of fractional composition (Table 1).

The mixer-activator used to obtain WFE and mechanoactivate diesel fuel contains four successively installed sections (Fig. 4) [18]. In the first section, vortex formation is carried out, in the second cavitation action, in the third - the total flow of the liquid medium is divided into small intersecting jets, in the fourth - the flow velocities are aligned.

\section{Investigation of the ignition and combustion characteristics of WFE and mechanoactivated diesel fuel droplets}

The experiments to study the combustion of WFE, mechanoactivated and original diesel fuel droplets were carried out using the "dropping technique" developed at the Institute of Chemical Physics [19 - 21]. According to this technique, a droplet of the studied energyintensive substance was applied to the junction of a microthermocouple (Fig. 5, $a, b$ ). A thermocouple with a droplet was installed inside the reaction chamber heated to a predetermined temperature. The signal from the thermocouple with a droplet, after appropriate amplification, was recorded on a loop oscilloscope. At the same time, the oscilloscope records the signal from the light sensor from the droplet (photodiode FD10K).

This method allows to obtain temperature values characterizing various stages of heating, ignition and combustion of a droplet, as well as to determine the temperature of the combustion products. The improvement of this method made it possible to carry out video recording of the processes occurring inside the reaction chamber.

The experiments were carried out using chromelalumel thermocouples with a diameter of 75-100 microns, which allowed keeping droplets of diesel fuel with a diameter of up to $1.5-2 \mathrm{~mm}$ on the junction. The temperature of the reaction chamber could vary in the range up to $1100{ }^{\circ} \mathrm{C}$ and was additionally controlled after the end of the experiment 
Table 1

Comparison of the component content in WFE obtained in TSTU and in diesel fuels

\begin{tabular}{|c|c|c|c|c|c|c|c|c|c|c|}
\hline \multirow[b]{3}{*}{ No. } & \multirow[b]{3}{*}{ Component } & \multicolumn{9}{|c|}{ Concentration of components in substances, $\%$ vol. } \\
\hline & & \multicolumn{2}{|c|}{ WFE 2018} & \multicolumn{4}{|c|}{ Non-activated diesel fuel } & \multicolumn{3}{|c|}{ Activated diesel fuel } \\
\hline & & $1 \mathrm{st}$ & 2nd & \multicolumn{2}{|c|}{$\begin{array}{l}\text { Diesel fuel } \\
\text { by VNIITiN }\end{array}$} & $\begin{array}{l}\text { Diesel } \\
\text { fuel by } \\
\text { Rosneft }\end{array}$ & $\begin{array}{c}\text { Diesel fuel } \\
\text { Euro } \\
\text { initial } \\
\end{array}$ & Euro & VNIITiN & $\begin{array}{l}57 \text { days } \\
\text { later }\end{array}$ \\
\hline 1 & \multirow{2}{*}{ Complex } & \multirow{2}{*}{2.0623} & \multirow{2}{*}{8.9733} & - & - & - & - & 18.7351 & - & 31.2393 \\
\hline 2 & & & & - & - & - & - & - & 12.4643 & 0.1744 \\
\hline 3 & Octane & 2.4137 & 1.4548 & 0.7914 & 0.6165 & 0.4710 & 0.7914 & 0.7627 & 0.5728 & 0.4770 \\
\hline 4 & Nonan & 5.3812 & 3.969 & 1.0773 & 2.0122 & 1.94 & 1.0773 & 0.8636 & 1.9178 & 1.4916 \\
\hline 5 & Decan & 10.6866 & 8.2844 & 1.6927 & 4.8365 & 4.17 & 1.6927 & 1.2876 & 4.3327 & 1.6204 \\
\hline 6 & $\mathrm{C} 11$ & 14.7484 & 11.56 & 3.7948 & 9.5619 & 7.87 & 3.7948 & 2.8221 & 7.0027 & 7.5722 \\
\hline 7 & $\mathrm{C} 12$ & 13.6303 & 11.10 & 7.9954 & 8.2222 & 8.859 & 7.9954 & 5.2168 & 7.4221 & 5.6975 \\
\hline 8 & $\mathrm{C} 13$ & 14.8227 & 11.725 & 10.1914 & 9.8051 & 13.05 & 10.1914 & 8.5468 & 8.8126 & 6.7065 \\
\hline 9 & $\mathrm{C} 14$ & 13.4622 & 10.2075 & 10.9121 & 10.6315 & 13.5569 & 10.9121 & 9.1103 & 9.4767 & 7.6143 \\
\hline 10 & $\mathrm{C} 15$ & 9.6852 & 9.318 & 9.2575 & 8.9045 & 10.981 & 9.2575 & 7.9060 & 7.7791 & 6.4032 \\
\hline 11 & $\mathrm{C} 16$ & 5.9617 & 6.696 & 9.8080 & 9.1511 & 10.15 & 9.8080 & 7.3523 & 8.2725 & 6.3928 \\
\hline 12 & $\mathrm{C} 17$ & 2.5920 & 3.76 & 7.8725 & 6.6586 & 6.627 & 7.8725 & 6.7942 & 5.5632 & 3.2984 \\
\hline 13 & Fitan & 0.9175 & 1.68 & 7.3010 & 3.5902 & 2.764 & 7.3010 & 6.2364 & 3.1828 & 1.3887 \\
\hline 14 & $\mathrm{C} 18$ & 1.4101 & 2.629 & 6.0368 & 5.5628 & 5.1 & 6.0368 & 5.1263 & 4.9620 & 3.3817 \\
\hline 15 & Pristane & 0.6511 & 1.463 & 4.0559 & 3.8064 & 3.0861 & 4.0559 & 3.2697 & 3.4556 & 2.5273 \\
\hline 16 & C19 & 0.7803 & 2.139 & 5.1226 & 4.6599 & 4.169 & 5.1226 & 4.4222 & 4.2337 & 3.4803 \\
\hline 17 & $\mathrm{C} 20$ & 0.4110 & 1.659 & 4.3236 & 3.8863 & 2.965 & 4.3236 & 3.6375 & 3.2585 & 3.0611 \\
\hline 18 & $\mathrm{C} 21$ & 0.1921 & 1.201 & 3.1886 & 2.9188 & 2.000 & 3.1886 & 2.8035 & 2.6214 & 2.3501 \\
\hline 19 & $\mathrm{C} 22$ & 0.1042 & 0.95 & 2.3509 & 2.2426 & 1.248 & 2.2509 & 2.1519 & 2.0158 & 2.0816 \\
\hline 20 & $\mathrm{C} 23$ & 0.0455 & 0.617 & 1.6067 & 1.4190 & 0.61 & 1.6067 & 1.4078 & 1.3158 & 1.4797 \\
\hline 21 & $\mathrm{C} 24$ & 0.0277 & 0.400 & 1.1408 & 0.9670 & 0,273 & 1.1408 & 0.9633 & 0.8627 & 0.9402 \\
\hline 22 & $\mathrm{C} 25$ & 0.0141 & 0.214 & 0.7005 & 0.5470 & 0,11 & 0.7005 & 0.5833 & 0.4753 & 0.6216 \\
\hline & Total & 100.0 & & 99.2203 & & & 100 & & & \\
\hline
\end{tabular}

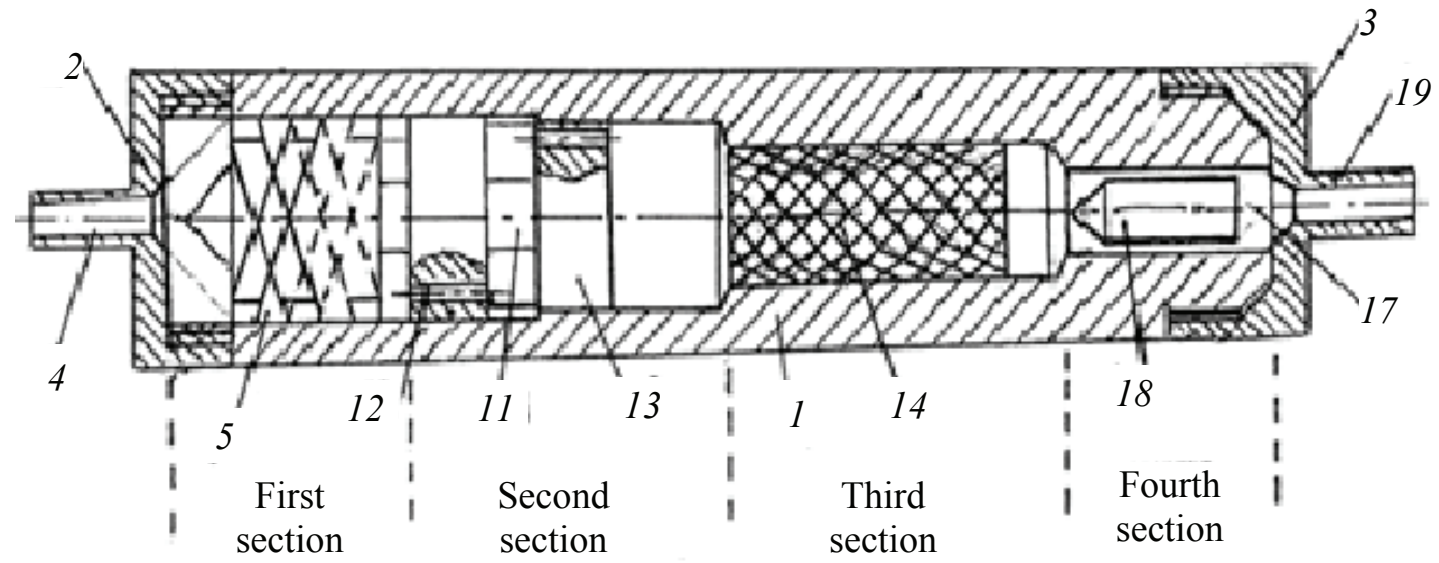

Fig. 4. Combined universal static mixer-activator (Patent RF No. 2550203 [18]) 


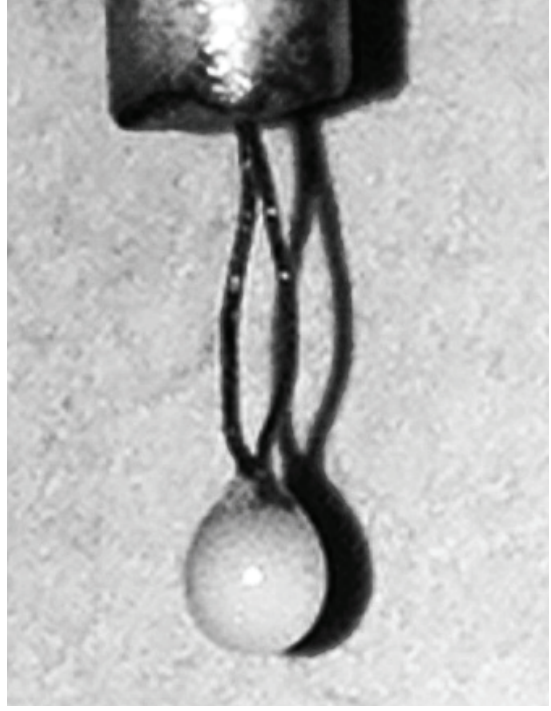

a)

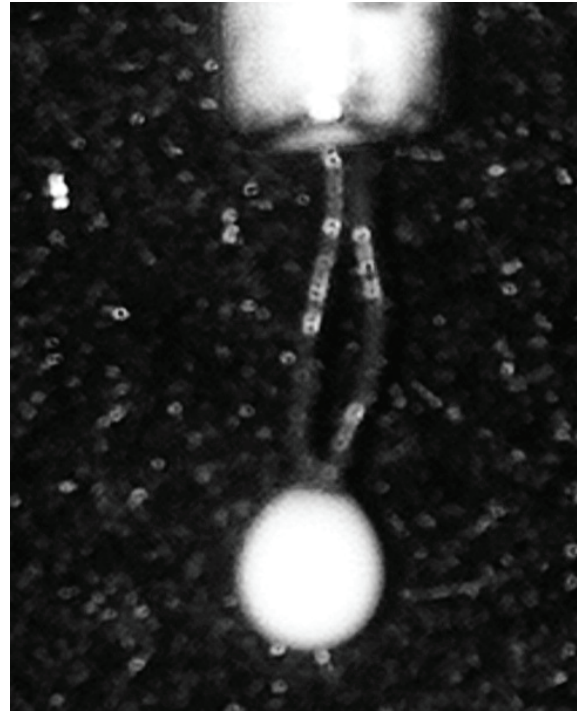

b)

Fig. 5. Photo of a droplet $(d=1.5 \mathrm{~mm})$ : $a$ - of the initial diesel fuel droplet (on a thermocouple); $b$ - of the fuel oil emulsion droplet (30\% water, $70 \%$ diesel fuel)

with a thermocouple holding a droplet. In most experiments, the chamber temperature did not exceed $500{ }^{\circ} \mathrm{C}$. The ignition temperature of the droplet $T_{i}$ was determined from the point of a pronounced inflection on the curve of the time variation of the droplet temperature (Fig. 6). As the results of the experiments show, the inflection point for WFE droplets corresponds to a temperature of $(100 \pm 10){ }^{\circ} \mathrm{C}$.

The oscillogram distinguishes two characteristic areas: 1 - relatively slow temperature variation of the droplet from initial temperature to ignition temperature $T_{i} ; 2$ - relatively rapid temperature rise from $T_{i}$ to $T_{\max }$ associated with the droplet ignition.

The results of finding the average values of temperature ignition in various types of fuel are presented in Table 2.

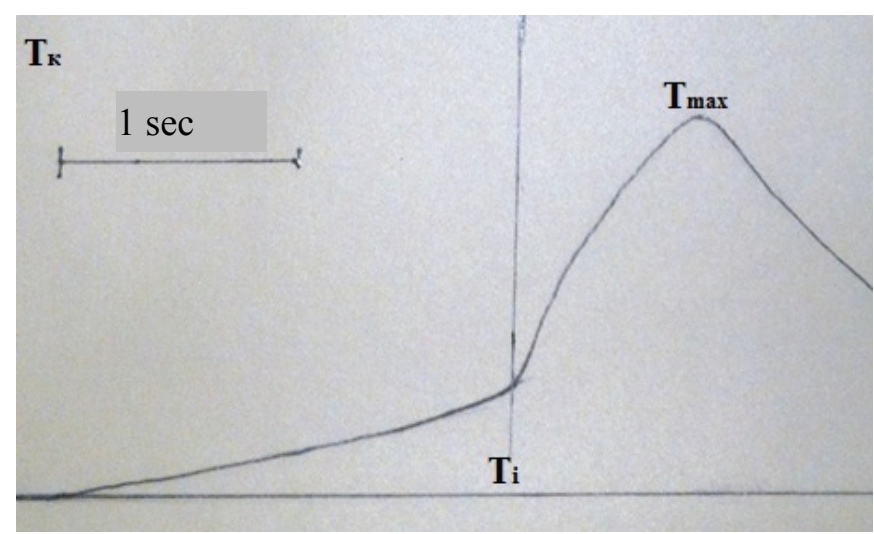

Fig. 6. Oscillogram of the temperature change of the WFE droplet
The data presented in Table 1 demonstrates that the mechanoactivated diesel fuel №1 has a lower flash point value compared to other diesel fuels. At the same time, the ignition temperature of the water-fuel emulsion is much lower and close to the boiling point of water. It is possible that the measured WFE ignition temperature is associated not only with the start of intense reactions in the gas phase, but also with the start of the destruction of the water-fuel emulsion droplet polydisperse structure (Fig. 7), which indirectly confirms the high quality of WFE preparation and its long durability, if it is prepared using the combined universal static mixer-activator [18].

Table 2

The values of the ignition temperature $T_{i}$ of diesel fuel, its mechanoactivated modifications and water-fuel emulsions in the air environment

\begin{tabular}{lcc}
\hline \multicolumn{1}{c}{ Type of fuel } & $T_{i},{ }^{\circ} \mathrm{C}$ & \multicolumn{1}{c}{ Notes } \\
\hline $\begin{array}{l}\text { Initial diesel fuel } \\
2010\end{array}$ & & \\
$\begin{array}{l}\text { Mechanoactivated } \\
\text { diesel fuel No. 3 2010 }\end{array}$ & $290 \pm 10$ & $\begin{array}{c}\text { Chamber temperature } \\
460{ }^{\circ} \mathrm{C}\end{array}$ \\
$\begin{array}{l}\text { Initial diesel fuel } \\
\text { 2018 }\end{array}$ & & \\
$\begin{array}{l}\text { Mechanoactivated } \\
\text { diesel fuel No. 1 2018 }\end{array}$ & $225 \pm 10$ & $\begin{array}{l}\text { Chamber temperature } \\
450{ }^{\circ} \mathrm{C}, \text { decrease in } T_{i}\end{array}$ \\
$\begin{array}{l}\text { Mechanoactivated } \\
\text { diesel fuel No. 2 2018 }\end{array}$ & $285 \pm 10$ & $\begin{array}{l}\text { Chamber temperature } \\
460{ }^{\circ} \mathrm{C}\end{array}$ \\
WFE (33 \% $\left.\mathrm{H}_{2} \mathrm{O}\right)$ & $100 \pm 10$ & $\begin{array}{l}\text { Chamber temperature } \\
460{ }^{\circ} \mathrm{C}, \text { low } T_{i}\end{array}$ \\
\hline
\end{tabular}




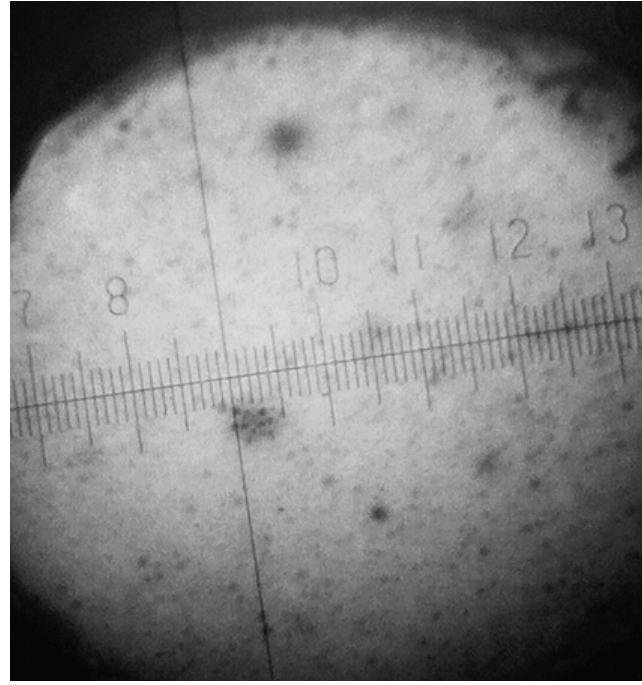

Fig. 7. Photo showing the polydisperse structure of a diesel fuel emulsion droplet with water (WFE 67/33, shelf life 8 months)

In addition to recording the temperature change in single droplets, a video recording of the process inside the reaction chamber was carried out. The photos presented in Fig. 8, $a-c$, correspond to the successive stages of the ignition and combustion process for a WFE droplet: the start of ignition, the separation and fall of a droplet, and the explosive combustion of a droplet (the time interval between shots is $30 \mathrm{~ms}$ ).

Fig. 8, $b$ shows that the inflection point, adopted as the ignition temperature of a WFE droplet, according to the dependence of the droplet temperature on time $\left((100 \pm 10){ }^{\circ} \mathrm{C}\right)$ corresponds to the moment of the droplet separation from the thermocouple, which is most likely associated with the decrease in the surface tension force of the droplet due to the ignition. In addition, Fig. 8, $b$ indicates the absence of the droplet explosion when separating from the thermocouple.

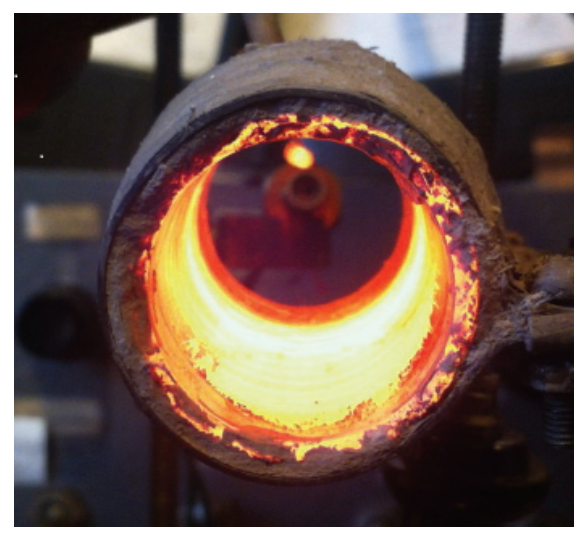

a)

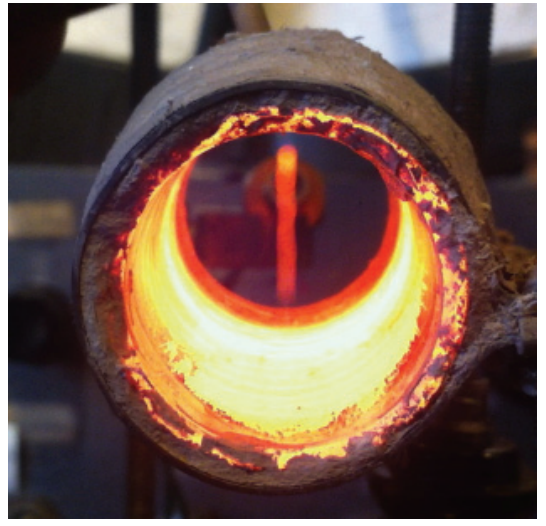

b)

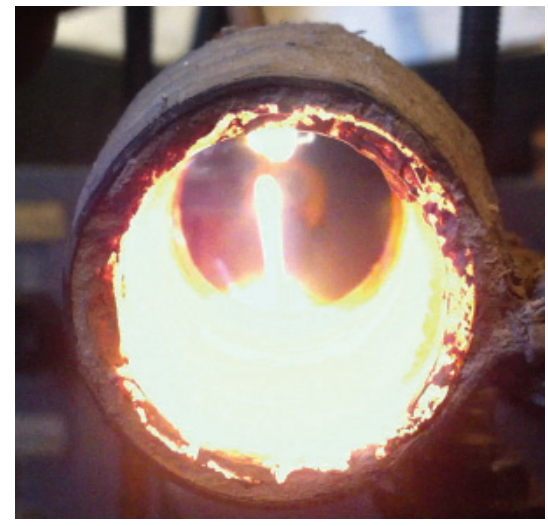

c)

Fig. 8. Photos of successive stages of the ignition and combustion process for a WFE droplet

The method of video registration does not allow to register the change in the diameter of a droplet during its combustion. For this reason, further studies of the process are planned, including the use of a falling combustion chamber [22].

\section{Conclusion}

1. The problem of increasing the energy efficiency of the heat engines, while reducing the content of harmful components in exhaust gases, was considered. It was shown that the solution to this problem is possible through the use of aqueous compositions of hydrocarbon fuels.

2. The advanced technology of preparing highly stable water-fuel emulsions of diesel fuel was tested using a combined universal static mixer-activator
(RF patent No. 2550203), as well as small additives of stabilizers-emulsifiers.

3. It was found experimentally that the WFE droplets retain their structure and physical-chemical properties for a rather long period of storage time (over 3 months).

4. It was defined experimentally that the ignition temperature of a water-fuel emulsion is significantly lower than the ignition temperatures of diesel fuels and is close to the boiling point of water.

The research was supported by the Ministry of Education and Science: for the Institute of Chemical Physics of the Russian Academy of Sciences - 49.23, Project 0082-2018-0004, state registration number of the topic - AAAA A18-118031590088-8, TSTU No. 9.7746.2017/BCh for 2017-2019. 


\section{References}

1. Assovskij I.G., Ryabikov O.B., Kutenyov V.F., Shabanov A.V. K Voprosu Vosplameneniya i Sgoraniya Obednennykh Smesej v DVS s Prinuditel'nym Zazhiganiem Novyj Etap [On the issue of ignition and combustion of lean mixtures in the ICE with forced ignition - a new stage]. Trudy NAMI, 2012, issue 247, pp. 64-75. (Rus)

2. Assovskij I.G., Kuznetsov G.P., Mikhajlov Yu.M. O gorenii Vodnykh Rastvorov Energoemkikh Sistem [On burning water solutions of energy-intensive systems]. Energeticheskie kondensirovannye sistemy, Chernogolovka Dzerzhinskij: IPHF RAN, 2012, pp. 15-18. (Rus)

3. Zel'dovich Ya.B., Sadovnikov P.Ya., FrankKamenetskij D.A. Okislenie Azota pri Gorenii [Nitrogen oxidation during combustion]. Moskva-Leningrad: Izdatel'stvo AN SSSR, 1947, 150 p. (Rus)

4. Pischinger F., Lepperhoff G., Houben M. Soot Formation and Oxidation in Diesel Engines. Soot Formation in Combustion, vol. 59, pp 382-395.

5. Aizam Shahroni Mohd Arshad, Yuzuru, Nada Yoshiyuki Kidoguchi, Daisuke Asao Shinichiro Yoshimura. Rapid emulsification of a fuel-water rapid internal mixing injector for emulsion fuel combustion. Energy, vol. 167, 2019, pp. 35-46.

6. Ivanov V.M., Kantorovich B.V. Toplivnye Emul'sii $i$ Suspenzii [Fuel emulsions and suspensions]. Moscow: Metallurgizdat, 1963, 183 p. (Rus)

7. Spejsher V.A., Gorbanenko A.D. Povyshenie Effektivnosti Ispol'zovaniya Gaza $i$ Mazuta v Energeticheskikh Ustanovkakh [Improving the gas and fuel oil efficiency in power plants]. Moscow: Energoizdat, 1982, $240 \mathrm{p}$.

8. Koryagin V.A. Szhiganie vodotoplivnykh Emul'sij $i$ Snizhenie Vrednyh Vybrosov [Water-fuel emulsion burning and emission reduction]. S-Pb.: Nedra, 1995, 304 p. (Rus)

9. Zavgorodnij B.V. Ustanovka dlya Prigotovleniya Vodotoplivnoj Emul'sii [Water-fuel emulsion preparation unit]. Patent SSSR № 1606725 (available at: https://patentdb.ru). (Rus)

10. Frolov S.M., Posvyanskij V.S., Basevich V.Ya., Belyaev A.A., Esmilaire O., Jablon C., Schmelzle P. Gorenie Chistogo i Emul'girovannogo Topliva [Clean and emulsified fuel burning]. Sovershenstvovanie Moshchnostnykh, Ekonomicheskikh $i$ Ekologicheskikh Pokazatelej DVS. Vladimir: Izd-vo V1GU, 2001, pp. 29-33. (Rus)

11. Strebkov D.S., Erhov M.V., Ross M.Yu., Kozhevnikov Yu.A. Sposob $i$ Ustrojstvo Polucheniya Smesevogo Topliva (Varianty) [Method and device for producing mixed fuel (versions)]. Patent RF № 2391384. (Rus)

12. Vorob'ev Yu.V., Teteryukov V.B. Sposob $i$ Ustrojstvo dlya Dozirovaniya $i$ Prigotovleniya ToplivnoVodnoj Emul'sii, Podavaemoj $v$ Karbyuratornye DVS [Method and device for dosing and preparing fuel-water emulsions supplied to carburetor internal combustion engines]. Patent RF № 2306447. (Rus)
13. Lomovskikh A.E., Vorob'ev Yu.V., Duplyak V.P. Strujnokavitacionnyj Ezhektor dlya Prigotovleniya Vodotoplivnoj Emul'sii [Jet cavitation ejector for preparing water-fuel emulsions]. Patent RF № 352805. (Rus)

14. Vorob'ev Yu.V., Teteryukov V.B. Vodnotoplivnaya Ehmul'siya [Water-fuel emulsion]. Patent RF № 2365618. (Rus)

15. Vorob'ev Yu.V., Dunaev A.V. Vozdejstvie na Motornye Topliva Priemami Mekhanokhimii dlya Uluchsheniya ikh Ekspluatacionnyh Pokazatelej [The impact on motor fuels by mechano-chemistry techniques to improve their performance]. Trudy GOSNITI, 2016, vol. 123, pp. 45-49. (Rus)

16. Serebryakov R.A., Stepanov A.P., Stekhin A.A. Kompozitsionnoe Toplivo [Composite fuel]. Trudy 7-j mezhd. n.-tekhn. konferentsii v GNU VIESKH, 2010, part 1, pp. 317-323. (Rus)

17. Strebkov D.S., Erhov M.V., Ross M.Yu., Kozhevnikov Yu.A. Sposob $i$ Ustrojstvo Polucheniya Smesevogo Topliva (varianty) [Method and device for producing mixed fuel (versions)]. Patent RF № 2391384. (Rus)

18. Vorob'ev Yu.V., Vorob'ev Yu.Yu. Kombinirovannyj Universal'nyj Staticheskij Smesitel'-aktivator [Combined universal static mixer-activator]. Patent RF № 2550203, B01F13/10, zayavka № 2012153260, opubl. 10.05.2015. (Rus)

19. Assovskii I.G., Kolesnikov-Svinarev V.I., Kuznetsov G.P., Yoo Kim. Critical Conditions for Single Droplets Ignition and Combustion. International Journal of Fluid Mechanics Research, Begell House, 1997, vol. 24, issue 1-3, pp. 307-313.

20. Assovskii I.G., Kolesnikov-Svinarev V.I., Kuznetsov G.P. Droplets Ignition of Aqueous Solutions of Hydrazine Nitrate. Colloquium on Dynamics of Explosions and Reactive Systems, Univ. of Mining and Metallurgy, Cracow, Poland, 1997, pp. 600.

21. Assovskij I.G., Kuznecov G.P., Nikitin E.A., Kolesnikov-Svinarev V.I. Kapel'nyj metod dlya Opredeleniya Vysokotemperaturnoj Kinetiki Razlozheniya Energoemkikh Zhidkikh Kompozitsij [Drip method for determining the high-temperature kinetics of decomposing energy-intensive liquid compositions]. Tezisy XXV konf. "Sovremennaya khimicheskaya fizika", Tuapse: IHF RAN, 2013, pp. 28. (Rus)

22. Kuznetsov G.P., Kolesnikov-Svinarev V.I., Assovskij I.G. O Gorenii Alyuminiya, Bora i ikh Kompozitsii v Kislorod Soderzhashchikh Sredakh [On the combustion of aluminum, boron and their composition in oxygen-containing media]. Gorenie $i$ vzryv, 2017, vol.10, issue 2, pp. 111-114. (Rus)

23. Baronin G.S., Buznik V.M., Mishchenko S.V., Rodionov Yu.V., Vorob'ev Yu.V., Ushakov N.V., Zavrazhin D.O., Kobzev D.E., Kuz'min A.P., Khrushchev S.P., Voronin N.V. Izdeliya iz SVMPEH-nanokompozitov, Poluchennye Objemnoj Shtampovkoj v Tverdoj Faze [Products from UHMWPE nanocomposites obtained by die forging in the 
solid phase]. Trudy XIV Vserossijskoj s mezhdunarodnym uchastiem shkoly-seminara po strukturnoj makrokinetike dlya molodykh uchenykh imeni akademika A.G. Merzhanova, Chernogolovka, 2016. pp. 13-20. (Rus)

24. Baronin G.S., Buznik V.M., Mishchenko S.V., Rodionov Yu.V., Vorob'ev Yu.V., Ushakov N.V., Zavrazhin D.O., Kobzev D.E., Kuz'min A.P., Khrushchev S.P., Voronin N.V. Polimernye Nanokompozity i Izdeliya na Osnove Sverhvysokomolekulyarnogo Polietilena (SVMPEH), Poluchennye Objemnoj Shtampovkoj v Tverdoj Faze [Polymer nanocomposites and products based on ultrahigh molecular weight polyethylene (UHMWPE) obtained by bulk stamping in the solid phase]. Trudy VIII Mezhdunarodnoj nauchno-innovatsionnoj molodezhnoj konferentsii, Tambov, 2016, pp. 28-34. (Rus)

25. Baronin G.S., Buznik V.M., Stolin A.M., Vorob'ev Yu.V., Ushakov N.V., Mishchenko S.V., Dmitriev V.M., Dmitriev O.S., Sychev M.V, Voronin N.V. Tverdofaznaya Tekhnologiya Pererabotki SVMPEH-nanokompozitov v Izdeliya i Mekhanokhimicheskie Processy v Uglevodorodnom Toplive s Ispol'zovaniem Gidrodinamicheskogo Mekhanoaktivatora [Solid-phase technology of processing UHMWPE nanocomposites into products and mechanochemical processes in hydrocarbon fuels using hydrodynamic mechanical activator]. Trudy XV Vserossijskoj $s$ mezhdunarodnym uchastiem shkoly-seminara po strukturnoj makrokinetike dlya molodykh uchenykh imeni akademika A.G. Merzhanova, Chernogolovka, 2017, pp. 26-31. (Rus)
26. Baronin G.S., Vorob'ev Yu.V., Ushakov N.V., Kornev M.B., Tsvetaev S.K., Golubchikov V.B., Khudyakov V.V., Sychev M.V., Voronin N.V. Formirovanie Strukturno-mekhanicheskih Svojstv Materialov i Izdelij iz SVMPEH-nanokompozitov Funkcional'nogo i Konstruktsionnogo Naznacheniya $\mathrm{V}$ Usloviyakh Tverdofaznoj Tekhnologii [Formation of structural and mechanical properties of materials and products from UHMWPE nanocomposites for functional and structural purpose in the solid-phase technology]. Materialy 8-j Mezhdunarodnoj konferencii SPACE-2017 «Kosmicheskij vyzov XXI veka. Perspektivnye materialy, tekhnologii $i$ pribory dlya kosmicheskikh ekspeditsij», Adler 2017, pp. 49-53. (Rus)

27. Vorob'ev Yu.V., Baronin G.S., Dunaev A.V., Stavrev D., Voronin N.V., Vorob'ev Yu.Yu., Kuznetsov G.P., Assovskij I.G. O Povyshenii Effektivnosti Teplovykh Mashin: Perspektivnaya Vodotoplivnaya Emul'siya [On improving the efficiency of heat engines: a promising water-fuel emulsion]. Gorenie $i$ vzryv, 2019. (Rus)

28. Vorob'ev Yu.V., Baronin G.S., Dunaev A.V., Stavrev D., Voronin N.V., Kuznecov G.P., Assovskij I.G. O Povyshenii Effektivnosti Teplovykh Mashin: Perspektivnaya Vodotoplivnaya Emul'siya [On improving the efficiency of heat engines: a promising water-fuel emulsion]. Trudy nauchnoi konferentsii po goreniyu i vzryvu, 2019, IHF RAN, Moscow. (Rus) 